\title{
FAKTOR - FAKTOR YANG MEMPENGARUHI KEPUTUSAN PEMBELIAN DAGING SAPI DI PASAR RAYA I SALATIGA
}

\author{
(Influencing Factors To The Beef Purchasing Decision In Pasar Raya 1 Salatiga)
}

Ega Jalu Nugroho dan Liska Simamora

Program Studi Agribisnis Fakultas Pertanian Universitas Kristen Satya Wacana

J1. Diponegoro 52-60 Salatiga 50711, Jawa Tengah-Indonesia

Penulis koresponden : $522016048 @$ student.uksw.edu

Article Submitted: $29-03-2021$

Article Accepted: 21-05-2021

\begin{abstract}
Pasar Raya 1 is one of the traditional markets located in the city of Salatiga. Pasar raya 1 is located on Jl. Jend. Sudirman, Kutowinangun Kidul Kec. Tingkir, Salatiga City, Central Java. Pasar Raya. This study aims to identify consumer characteristics, analyze the effect of price, service quality, lifestyle, product quality, place, promotion. This research was conducted in August - December 2020 in the City of Salatiga. This type of research uses quantitative descriptive, the sampling method used in this research is purposive sampling by determining criteria, namely anyone who has made a purchase and is willing to be interviewed. Samples were collected as many as 70 respondents, namely the criteria for beef consumers in Pasar Raya 1. The analytical method used is multiple regression analysis techniques. The results showed that: 1 . The Characteristics of the most respondents, 64 (93\%) were female, 32 (45.7\%) aged 40-49 years, based on the education level of 26 people (37.1\%) SMA, the factors that have a significant effect are price (X1), product quality (X4), place (X5), while for service quality (X2), lifestyle (X3), promotion (X4), do not have a significant effect on purchasing decisions.
\end{abstract}

Keywords: purchasing decision, beef meat

\section{PENDAHULUAN}

Perkembangan penduduk di Indonesia mengakibatkan kebutuhan akan pangan terus meningkat. Karena, pangan merupakan kebutuhan penting setiap manusia yang harus dipenuhi.Usaha penciptaan sumber daya manusia yang berkualitas tentunya sangat dipengaruhi oleh beberapa faktor, antara lain faktor pangan (unsur gizi), kesehatan, pendidikan, informasi, teknologi dan jasa pelayanan lain. Peranan yang paling penting dari beberapa faktor tersebut yaitu unsur gizi,dimana seseorang yang kekurangan gizi akan mengalami gangguan pertumbuhan dan perkembangan.
Daging merupakan salah satu komoditas pertanian yang diperlukan untuk memenuhi kebutuhan protein, karena daging mengandung protein yang bermutu tinggi, yang mampu menyumbangkan asam amino esensial yang lengkap.daging didefinisikan sebagai bagian dari hewan potong yang digunakan manusia sebagai bahan makanan, selain mempunyai penampakan yang menarik selera, juga merupakan sumber protein hewani berkualitas tinggi. Daging adalah seluruh bagian dari ternak yang sudah dipotong dari tubuh ternak kecuali tanduk, kuku, tulang dan bulunya. Dengan demikian hati, limpa, otak, dan isi perut seperti usus juga termasuk daging. 
Saat ini banyak pedagang berkompetisi untuk menguasai pangsa pasar yang ada, yaitu dengan cara membuat perencanaan pemasaran yang baik demi mendapat pencitraan yang positif di benak konsumen. Kualitas produk yang berkualitas berperan penting dalam membentuk kepuasan konsumen, selain itu juga erat kaitannya dalam menciptakan keuntungan bagi pedagang. Semakin berkualitas produk yang diberikan oleh pedagang maka kepuasan yang dirasakan oleh konsumen akan semakin tinggi. kepuasan konsumen menjadi tujuan utama pedagang serta senantiasa memberikan ciri pembeda dengan produk pesaing.

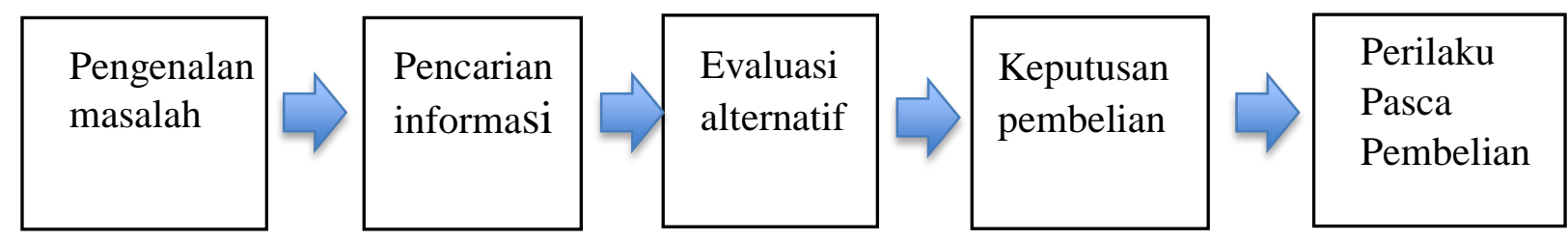

Sumber: Kotler (2008)

Gambar 1. Proses Keputusan Pembelian

Keputusan pembelian merupakan pemikiran dimana individu mengevaluasi berbagai pilihan dan memutuskan pilihan pada suatu produk dari sekian banyak pilihan. Proses terjadinya keputusan pembelian harus melalui 5 tahapan yaitu: pengenalan masalah, pencarian informasi, evaluasi alternatif, keputusan pembelian, perilaku pasca pembelian. Proses pembelian dimulai jauh sebelum pembelian sesungguhnya dan berlanjut dalam waktu yang lama setelah pembelian Kotler dan Keller (2009-:234-244).

Faktor yang mempengaruhi dengan keputusan pembelian dapat dilihat dari segi keadaan dan situasi lapisan masyarakat dimana dilahirkan dan berkembang mempengaruhi perilaku konsumen. Ini berarti konsumen berasal dari lapisan masyarakat atau lingkungan yang berbeda akan mempunyai pendapat, penilaian, sikap, kebutuhan dan selera yang berbeda-beda sehingga dalam tahap pengambilan keputusan pembelian akan dipengaruhi oleh beberapa faktor (Kotler, 2008). Berikut faktor yang mempengaruhi keputusan pembelian, diantaranya: Faktor Internal yang meliputi gaya hidup yang didefinisikan sebagai pola dimana orang hidup dan mengahbiskan waktu, serta uang. Gaya hidup adalah fungsi motivasi konsumen dan pembelajaran sebelumnya, kelas sosial, demografi dan perubahanya.

Faktor Eksternal yang meliputi harga yaitu ukuran terhadap besar kecilnya nilai kepuasan seseorang terhadap produk yang dibelinya. Seseorang akan berani membayar suatu produk dengan harga yang mahal apabila dia mendapatkan kepuasan yang diharapkannya terhadap produk yang akan dibelinya. Pembeli akan memilih tempat yang benar-benar nyaman dan tidak membutuhkan terlalu banyak waktu, tenaga, dan biaya untuk sampai ke tempat tersebut, seperti mudah dijangkau dan dekat dengan fasilitas-fasilitas umum, sehingga tempat ini dapat mendukung faktor yang lainnya. Selain tempat, Lokasi penjualan merupakan bagian penting dalam saluran distribusi. Lokasi yang baik menjamin tersedianya akses dengan cepat, dan sejumlah besar konsumen dan cukup kuat untuk mengubah pola berbelanja dan pembelian konsumen. (Swasta dan Handoko, 2000).Salah satu nilai utama yang diharapkan oleh pelanggan dari pemasok adalah mutu produk dan jasa yang 
tinggi. Maka dari pernyataan tersebut dapat dinyatakan bahwa mutu atau kualitas produk dapat mempengaruhi konsumen dalam memutuskan untuk memperoleh produk tersebut. Kualitas produk berarti kualitas kesesuain bebas dari kecacatan dan kekonsistenan dalam memberikan tingkatan kualitas yang akan dicapai atau dijanjikan. (Kotler dan Keller, 2007).

Promosi adalah upaya untuk memberitahukan atau menawarkan produk atau jasa dengan tujuan menarik calon konsumen untuk membeli atau mengkonsumsi-nya. Dengan adanya promosi produsen atau distributor mengharapkan kenaikan angka penjualan. Kegiatan ini merupakan kegiatan yang sangat penting dengan cara mempromosikan, baik itu produk, harga, dan lokasi. Dalam kegiatan ini setiap perusahaan berusaha untuk mempromosikan seluruh produk dan jasa yang dimilikinya baik langsung maupun tidak langsung (Kasmir, 2004). Selain itu adalah kualitas pelayanan yang memiliki hubungan yang sangat erat dengan keputusan pembelian, yaitu kualitas memberikan suatu dorongan kepada konsumen untuk menjalani ikatan dengan perusahaan.

\section{METODE PENELITIAN}

Penelitian dilaksanakan pada bulan Agustus - Desember 2020 di Pasar Raya 1 lantai 2 yang terletak di Jalan Jendral Sudirman, Salatiga, Jawa Tengah. Penelitian ini menggunakan deskriptif kuantitatif dengan metode survei yang menggunakan kuesioner sebagai alat penelitian sebagaimana yang dikemukakan oleh Sugiyono 2012 bahwa metode penelitian yang digunakan untuk meneliti populasi atau sampel tertentu, analisis data bersifat kuantitatif atau statistik, dengan tujuan untuk menguji hipotesis yang telah diterapkan.

Sumber data yang digunakan dalam penelitian ini adalah data primer, . Data primer yang digunakan dalam penelitian ini adalah bersumber dari penyebaran kuesioner secara langsung kepada responden. Teknik pengambilan sampel menggunakan non probability sampling. Sampel yang dipilih menggunakan teknik purposive sampling dengan cara menetapkan kriteria yaitu siapa saja yang telah melakukan pembelian dan bersedia untuk diwawancarai. Dalam penelitian ini kriteria yang digunakan dalam penelitian sampel adalah orang yang membeli daging sapi di Pasar Raya 1 lantai 2 Kota Salatiga. Jumlah responden yang baik disarankan untuk mencapai keakuratan antara 30 - 500 responden. Maka jumlah responden yang akan digunakan di penelitian ini adalah 70 responden.

\section{HASIL DAN PEMBAHASAN}

\section{Gambaran Umum}

Pasar raya 1 merupakan salah satu pasar tradisional yang terletak di kota Salatiga. Pasar raya 1 terletak di Jl. Jend. Sudirman, Kutowinangun Kidul Kec. Tingkir, Kota Salatiga, Jawa Tengah, Di pasar raya 1 terdapat 25 pedagang aktif yang selalu memperjualbelikan produk daging sapinya di pasar raya 1 . Terdapat 9 orang pedagang daging sapi yang memotong daging sapinya di Rumah Potong Hewan Salatiga,selain itu 11 pedagang lainya membeli dagangan mereka dari pedagang lainnya di kota lain untuk dijual kembali di pasar raya 1,5 pedagang yang membeli daging dari pedagang lain di pasar raya 1 .

\section{Karakteristik Responden}

70 responden pembeli daging sapi di Pasar Raya 1 responden perempuan sebanyak 64 orang atau 93,4 persen, sehingga pada kategori ini responden perempuan lebih dominan daripada responden laki-laki dikarenakan perempuan lebih sering belanja kebutuhan sehari - hari dibandingkan laki - laki. Dari kategori usia, responden yang paling dominan pada usia 40-49 tahun dengan persentase $45,7 \%$ paling banyak daripada kategori usia lain. Responden penelitian ini paling banyak 
berasal dari jenjang pendidikan SMA kategori pendidikan lainnya. sebanyak $37,1 \%$ paling banyak daripada

Tabel 1. Karakteristik Responden Berdasarkan jenis Kelamin,Umur dan Tingkat Pendidikan

\begin{tabular}{llcc}
\hline & Identitas Responden & (Orang) & $(\%)$ \\
\hline \multirow{4}{*}{ Jenis Kelamin } & Laki-laki & 6 & 8,6 \\
& Perempuan & 64 & 93,4 \\
& Jumlah & 70 & 100 \\
\hline \multirow{5}{*}{ Usia } & $<30$ & 8 & 11,5 \\
& $31-39$ & 18 & 25,7 \\
& $40-49$ & 32 & 45,7 \\
& 50-60 & 12 & 17,1 \\
& Jumlah & 70 & 100 \\
\hline \multirow{5}{*}{ Pendidikan } & SD & 20 & 28,6 \\
& SMP & 21 & 30 \\
& SMA & 26 & 37,1 \\
& D1/D3/S1 & 3 & 4,3 \\
& Jumlah & 70 & 100 \\
\hline
\end{tabular}

Sumber: Data primer yang diolah 2021.

\section{Uji Validitas}

Tabel 2 Uji Validitas

\begin{tabular}{|c|c|c|c|c|}
\hline Variabel & Pernyataan & $\mathrm{R}$ hitung & R tabel & Keterangan \\
\hline \multirow{5}{*}{ Harga } & $\mathrm{X} 1.1$ & 0.840 & 0.198 & Valid \\
\hline & $\mathrm{X} 1.2$ & 0.654 & 0.198 & Valid \\
\hline & $\mathrm{X} 1.3$ & 0.682 & 0.198 & Valid \\
\hline & $\mathrm{X} 1.4$ & 0.783 & 0.198 & Valid \\
\hline & $\mathrm{X} 1.5$ & 0.280 & 0.198 & Valid \\
\hline \multirow{4}{*}{ Kualitas Pelayanan } & $\mathrm{X} 2.1$ & 0.647 & 0.198 & Valid \\
\hline & $\mathrm{X} 2.2$ & 0.718 & 0.198 & Valid \\
\hline & $\mathrm{X} 2.3$ & 0.800 & 0.198 & Valid \\
\hline & $\mathrm{X} 2.4$ & 0.788 & 0.198 & Valid \\
\hline \multirow{3}{*}{ Gaya Hidup } & $\mathrm{X} 3.1$ & 0.739 & 0.198 & Valid \\
\hline & X 3.2 & 0.705 & 0.198 & Valid \\
\hline & $\mathrm{X} 3.3$ & 0.886 & 0.198 & Valid \\
\hline \multirow{4}{*}{ Kualitas Produk } & $\mathrm{X} 4.1$ & 0.736 & 0.198 & Valid \\
\hline & $\mathrm{X} 4.2$ & 0.880 & 0.198 & Valid \\
\hline & $\mathrm{X} 4.3$ & 0.695 & 0.198 & Valid \\
\hline & $\mathrm{X} 4.4$ & 0.742 & 0.198 & Valid \\
\hline \multirow{4}{*}{ Tempat } & $\mathrm{X} 5.1$ & 0.746 & 0.198 & Valid \\
\hline & $\mathrm{X} 5.2$ & 0.777 & 0.198 & Valid \\
\hline & X5.3 & 0.726 & 0.198 & Valid \\
\hline & X5.4 & 0.631 & 0.198 & Valid \\
\hline \multirow[b]{3}{*}{ Promosi } & X6.1 & 0.821 & 0.198 & Valid \\
\hline & X6.2 & 0.879 & 0.198 & Valid \\
\hline & X6.3 & 0.872 & 0.198 & Valid \\
\hline
\end{tabular}




\begin{tabular}{lllll}
\hline Keputusan Pembelian & Y1 & 0.418 & 0.198 & Valid \\
& Y2 & 0.754 & 0.198 & Valid \\
& Y3 & 0.742 & 0.198 & Valid \\
& Y4 & 0.748 & 0.198 & Valid \\
\hline
\end{tabular}

Sumber: Data primer yang diolah 2021.

Hasil pengujian validitas diatas masing - masing indikator dari variabel Harga, Kualitas Pelayanan, Gaya Hidup, Kualitas Produk, Tempat, Promosi,terhadap keputusan pembelian didapatkan nilai koefisien korelasi lebih besar dari $\mathrm{r}$ tabel. Dengan $\mathrm{n}=70$ pada tingkat signifikansi $5 \% \mathrm{r}$ tabel $=0,198$ sehingga dapat dinyatakan valid.

\section{Uji Reliabilitas}

Hasil uji reliabilitas kuesioner keseluruhan indikator dari 6 variabel yang meliputi Harga, Kualitas Pelayanan, Gaya Hidup, Kualitas Produk, Tempat, Promosi terhadap keputusan pembelian mendapatkan nilai cronbach alpha lebih besar > 0,60 dan masing - masing nilai reliabilitasnya tinggi sehingga dapat dikatakan reliable.

Tabel 3. Uji Reliabilitas

\begin{tabular}{lcc}
\hline Variabel & Cronbach Alpha & Keterangan \\
\hline Harga & 0.666 & Reliabel \\
Kualitas Pelayanan & 0.721 & Reliabel \\
Gaya Hidup & 0.679 & Reliabel \\
Kualitas Produk & 0.763 & Reliabel \\
Tempat & 0.687 & Reliabel \\
Promosi & 0.819 & Reliabel \\
Keputusan Pembelian & 0.605 & Reliabel \\
\hline
\end{tabular}

Sumber: Data Primer (2021)

\section{Uji Normalitas}

Terlihat sebaran titik-titik gambar mendekati garis diagonal sehingga data dikatakan normal.

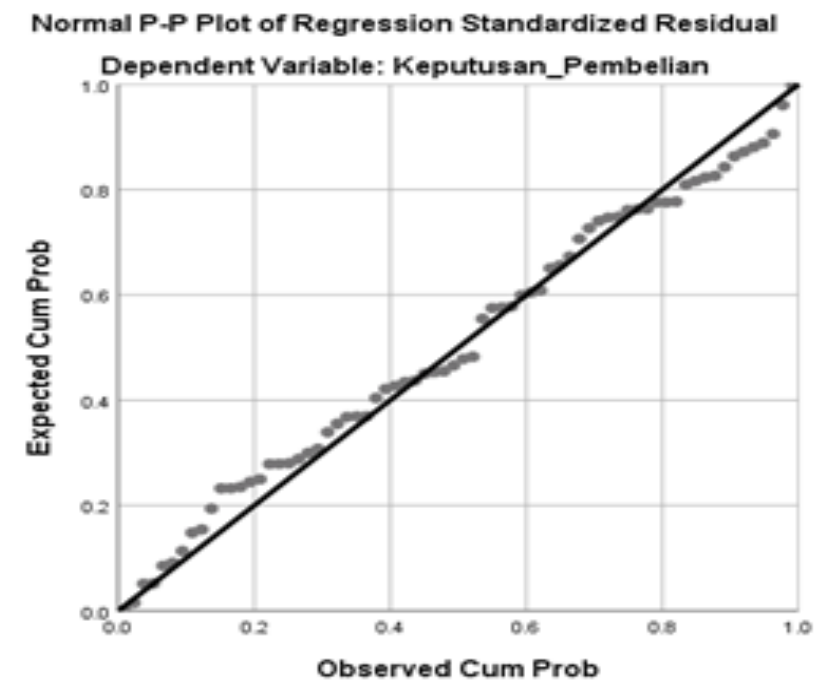

Gambar 1. Uji normalitas

Sumber: Data Output SPSS 2021 


\section{Uji Multikolinearitas}

Uji multikolinearitas digunakan untuk menguji model regresi dengan tujuan apakah adanya korelasi antar variabel bebas. Salah satu metode uji yaitu dengan mengetahui nilai tolerance dan variance inflation faktor (VIF). Nilai tolerance digunakan untuk mengukur variabilitas variabel independen yang terpilih dan tidak dijelaskan oleh variabel lainnya.( Setyarko, 2016 ).

Tabel 4. Uji Multikolinearitas

\begin{tabular}{lcc}
\hline \multicolumn{1}{c}{ Model } & Collinearity Statistics \\
\hline Harga & 0.184 & VIF \\
Kualitas Pelayanan & 0.153 & 5,424 \\
Gaya Hidup & 0.691 & 6,531 \\
Kualitas Produk & 0.867 & 1,447 \\
Tempat & 0.770 & 1,153 \\
Promosi & 0.454 & 1.298 \\
\hline
\end{tabular}

Berdasarkan data diatas dapat diketahui bahwa untuk lolos dari uji multikolinearitas sudah terpenuhi oleh seluruh variabel independen yang ada, yaitu nilai tolerance lebih besar dari 0,10 dan nilai VIF ( variance inflation factor ) lebih kecil dari 10. Dengan melihat tabel diatas sudah jelas bahwa tidak terjadi multikolinearitas ketidaksamaan variance atau residual satu pengamatan ke pengamatan lain. . Dasar yang digunakan adalah jika terdapat pola tertentu maka terjadi heteroskedastisitas, jika tidak terdapat pola yang jelas seperti titiktitik yang menyebar diatas dan dibawah angka 0 pada sumbu $\mathrm{Y}$, maka tidak terjadi heteroskesdisitas.

\section{Uji Heteroskedastisitas}

Uji heteroskedastisitas digunakan untuk menguji apakah model regresi terjadi

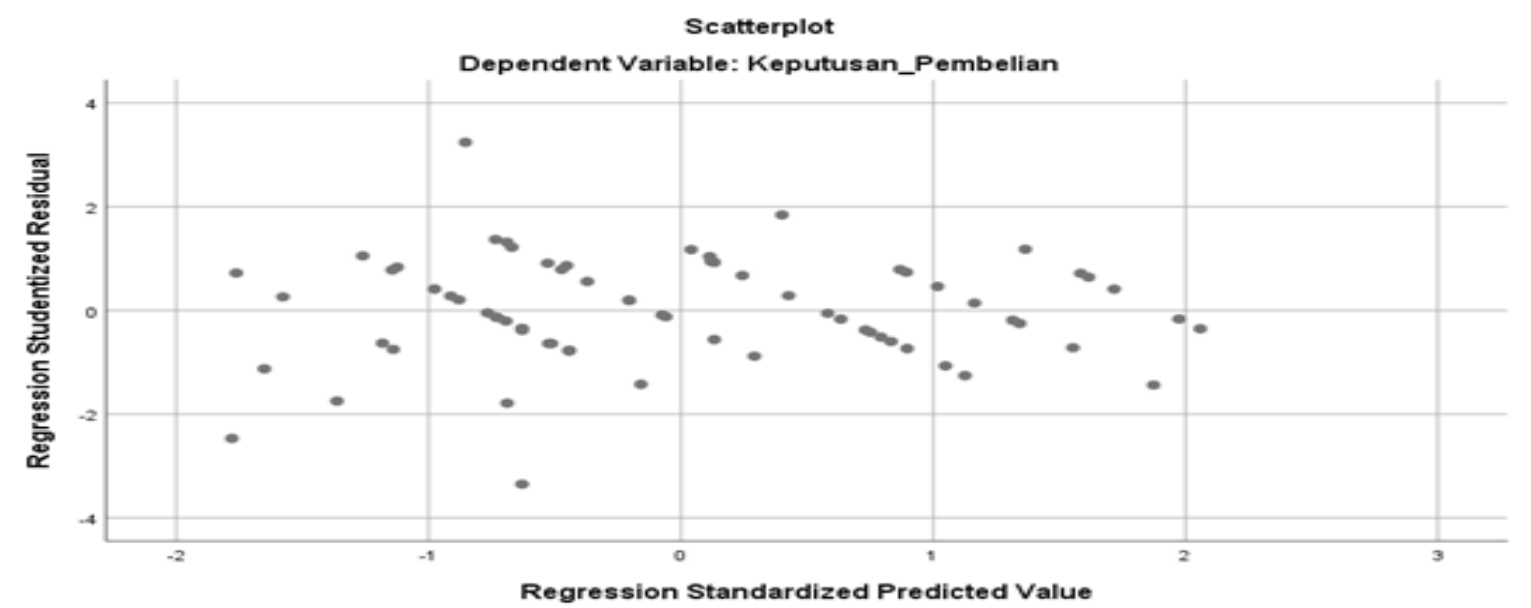

Gambar 2. Hasil Uji Heteroskedastisitas

Sumber: Data Output SPSS 2021.

Berdasarkan gambar hasil scatterplot menyebar dan tidak membentuk pola tertentu sehingga tidak terdapat heteroskedastisitas. 


\section{Koefisien determinasi}

Dari table di bawah dapat dilihat nilai $R$ Square dari model regresi ini adalah 0,832 atau $83,2 \%$, nilai tersebut berarti $83,2 \%$ variabel dependen (keputusan pembelian) dapat dijelaskan oleh variabel independen (harga, kualitas pelayanan, gaya hidup, kualitas produk, tempat dan promosi), sisanya sebesar $16,8 \%$ dijelaskan variabel lain diluar penelitian.

Tabel 5. Hasil Koefisien Determinasi

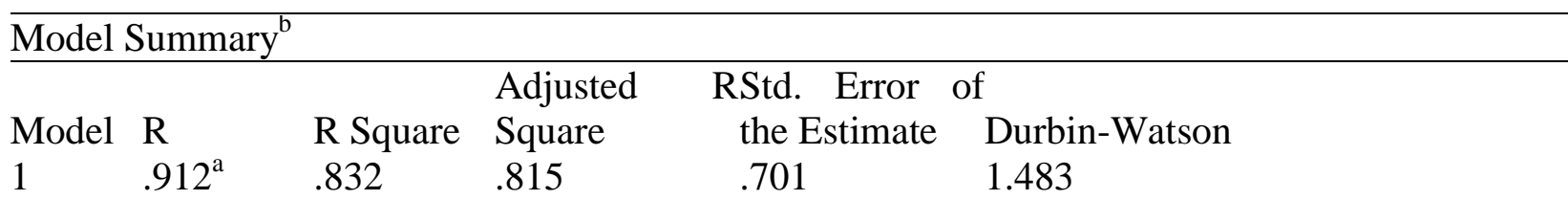

Keterangan : a. Predictors: (Constant), Promosi, Kualitas Produk, Gaya Hidup, Tempat, Harga, Kualitas Pelayanan

b. Dependent Variable: Keputusan Pembelian

Sumber: Data Output SPSS (2021)

\section{Uji Signifikan Simultan (f)}

Dari hasil uji statistik diatas dapat diketahui nilai Sig. F adalah 0,000 sehingga kurang dari alfa 0,05 maka dapat disimpulkan secara simultan (bersama-sama) variabel harga, kualitas pelayanan, gaya hidup, kualitas produk, tempat dan promosi berpengaruh terhadap kepuasan konsumen.

Tabel 6. Hasil Uji Simultan (F)

\begin{tabular}{|c|c|c|c|c|c|c|}
\hline \multicolumn{7}{|c|}{ ANOVA } \\
\hline \multicolumn{2}{|c|}{ Model } & $\begin{array}{l}\text { Sum of } \\
\text { Squares }\end{array}$ & $\mathrm{df}$ & Mean Square & \multirow{2}{*}{$\begin{array}{l}\mathrm{F} \\
51.823\end{array}$} & \multirow{2}{*}{$\begin{array}{l}\text { Sig. } \\
.000^{\mathrm{b}}\end{array}$} \\
\hline 1 & Regression & 152.953 & 6 & 25.492 & & \\
\hline & Residual & 30.990 & 63 & .492 & & \\
\hline & Total & 183.943 & 69 & & & \\
\hline
\end{tabular}

Keterangan : a. Dependent Variable: Keputusan Pembelian

b. Predictors: (Constant), Promosi, Kualitas Produk, Gaya Hidup, Tempat, Harga, Kualitas Pelayanan

Sumber: Data Output SPSS 2021

\section{Uji Signifikan Parsial (t)}

Dari tabel dibawah dapat dilihat pengaruh masing - masing variabel terhadap keputusan pembelian, dengan menetapkan nilai signifikansi $0,00<0,05$. Dari tabel 7 diketahui nilai sig 0.00 dengan koefisien sebesar 0,536, yang artinya nilai sig lebih kecil dari nilai probabilitas $0,05 \quad(0,00<$ 0,05). Hal tersebut menunjukan bahwa variabel harga (X1) berpengaruh secara signifikan dan positif terhadap keputusan pembelian daging sapi.Hasil tersebut didukung oleh penelitian yang pernah dilakukan oleh Hamka (2014), harga memberikan pengaruh yang signifikan terhadap keputusan pembelian konsumen terhadap ayam potong di pasar Gamalama. Semakin cocok harga yang ditawarkan oleh produsen terhadap konsumen, maka semakin kuat keputusan pembelian yang akan dilakukan oleh konsumen terhadap ayam potong.

Berdasarkan hasil analisis di atas diketahui nilai sig 0,22 dengan koefisien sebesar $-0,180$, yang artinya nilai sig lebih besar dari nilai probabilitas $0,05(0,22>$ 
0,05). Hal tersebut menunjukan bahwa variabel kualitas pelayanan (X2) tidak berpengaruh secara signifikan terhadap keputusan pembelian daging sapi. Hasil tersebut berbeda dengan penelitian yang pernah dilakukan sebelumnya oleh Tatag (2019) yang mengemukakan bahwa kualitas pelayanan berpengaruh secara parsial terhadap kepuasan pelanggan pada Pt. Anzindo gratia international daging sapi beku dan segar. Hal ini terjadi karena pasar raya 1 merupakan salah satu pasar tradisional yang dimana tidak menetapkan aturan tertentu mengenai kualitas pelayanan.

Tabel 7. Hasil Uji Signifikansi parsial

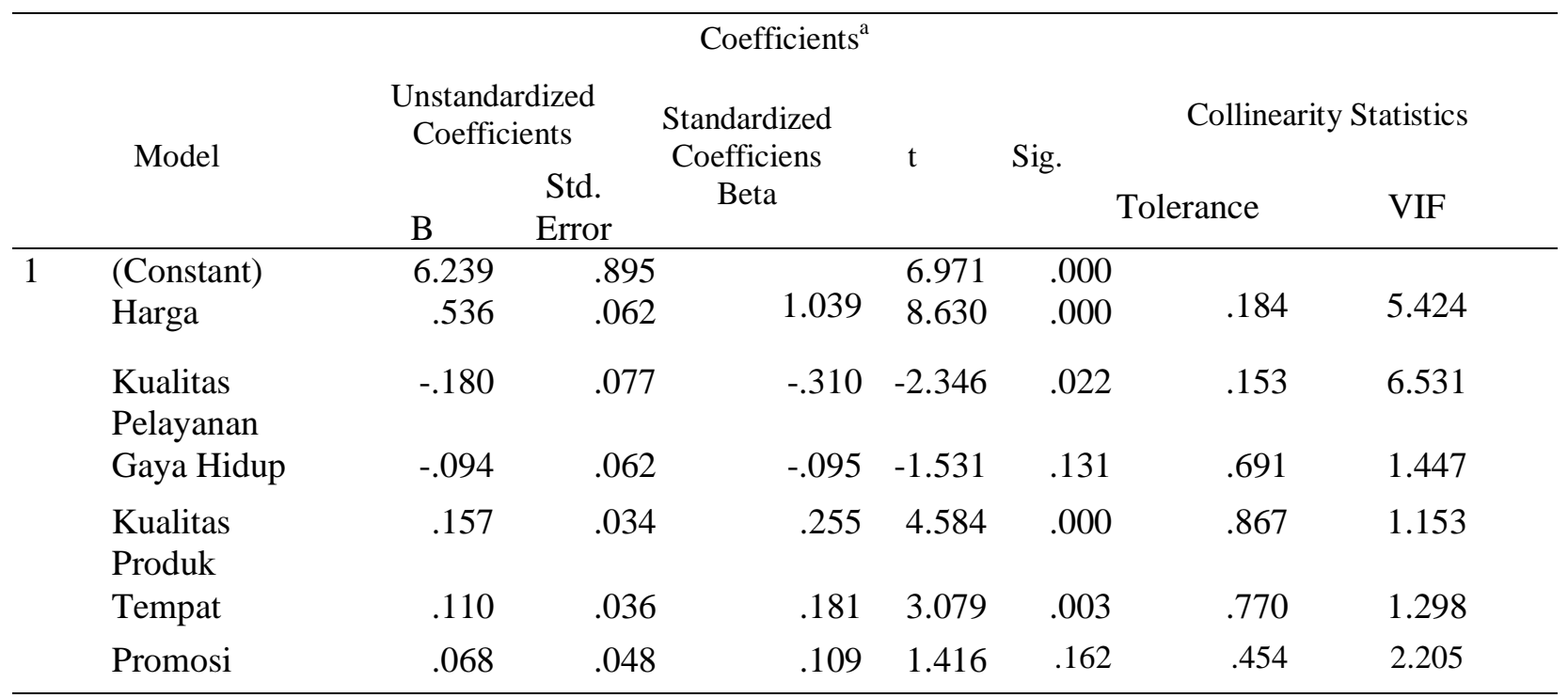

Keterangan : a. Dependent Variable: Keputusan_Pembelian

Sumber: Data primer yang diolah 2021.

Dari tabel diatas dapat dilihat bahwa nilai sig 1,31 dengan koefisien sebesar 0,094, yang artinya nilai sig lebih besar dari nilai probabilitas $0,05(1,31>0,05)$. Hal ini menunjukan bahwa variabel gaya hidup (X3) tidak berpengaruh secara signifikan terhadap keputusan pembelian daging sapi. Maka dari itu konsumen daging sapi di Pasar Raya I memiliki kecenderungan mengkonsumsi daging sapi berbeda - beda. Karena ada juga konsumen yang memiliki usaha olahan daging sapi untuk dijadikan produk olahan makanan tertentu.

Dari tabel diatas dapat dilihat nilai sig 0,00 dengan koefisien sebesar 0,157, yang artinya nilai sig lebih kecil dari nilai probabilitas $0,05(0,00<0,05)$. Hal ini menunjukan bahwa variabel kualitas produk (X4) berpengaruh secara signifikan terhadap keputusan pembelian daging sapi. Hasil tersebut didukung oleh penelitian yang pernah dilakukan oleh Hamka (2014), Kualitas memberikan pengaruh yang signifikan terhadap keputusan pembelian, dimana konsumen akan melakukan pembelian jika kualitas ayam potong yang ditawarkan sesuai dengan keinginan konsumen

Berdasarkan tabel diatas dapat dilihat nilai sig 0,03 dengan koefisien sebesar 0,110 , yang artinya nilai sig lebih kecil dari nilai probabilitas $0,05(0,03<0,05)$. Hal ini menunjukan bahwa variabel tempat (X5) berpengaruh secara signifikan terhadap keputusan pembelian daging sapi, Karena tempat yang strategis dan mudah dijangkau akan memudahkan konsumen untuk mendapatkan produk, dalam hal ini adalah daging sapi yang berada di Pasar Raya I. Hasil penelitian ini sejalan dengan penelitian sebelumnya yang dilakukan oleh Dhita, et all ( 2016 ) Tempat diartikan 
bagaimana perusahaan membuat produk atau jasanya tersedia dalam jumlah dan lokasi yang tepat ketika konsumen memerlukan produk atau jasa tersebut. Pemilihan lokasi memerlukan pertimbangan yang nantinya akan berpengaruh terhadap keputusan pembelian konsumen. Beberapa hal yang perlu diperhatikan adalah akses menuju lokasi misalnya mudah dijangkau dengan sarana transportasi umum, visibilitas (lokasi strategis), kondisi lingkungan.

Berdasarkan tabel diatas dapat dilihat nilai sig 1,62 dengan koefisien sebesar 0,068 , yang artinya nilai sig lebih besar dari nilai probabilitas $0,05(1,62>0,05)$. Hal ini menunjukan bahwa variabel promosi (X6) tidak berpengaruh signifikan terhadap minat konsumen untuk membeli. Artinya ada atau tidaknya promosi tidak berpengaruh signifikan terhadap keputusan pembelian daging sapi di Pasar Raya I. Hasil tersebut didukung oleh penelitian yang di dilakukan oleh Yasir, et all (2019) menyatakan variabel promosi tidak berpengaruh signifikan terhadap variabel pembelian konsumen

\section{Persamaan Regresi}

Adapun model persamaan regresi tersebut adalah sebagai berikut:

$$
\begin{aligned}
\mathrm{Y}= & \mathrm{a}+\mathrm{b} 1 \mathrm{X} 1+\mathrm{b} 2 \mathrm{X} 2+\mathrm{b} 3 \mathrm{X} 3+\mathrm{b} 4 \mathrm{X} 4+\mathrm{bX} 5 \\
& +\mathrm{e} \\
\mathrm{Y}= & 6,239+0,536 \mathrm{X} 1-0,180 \mathrm{X} 2- \\
& 0,094 \mathrm{X} 3+0,157 \mathrm{X} 4+0.110 \mathrm{X} 5+ \\
& 0.068 \mathrm{X} 6+\mathrm{e} \\
\mathrm{Y}= & \text { Keputusan Pembelian } \\
\mathrm{X} 1= & \text { Harga } \\
\mathrm{X} 2= & \text { Kualitas Pelayanan } \\
\mathrm{X} 3=\text { Gaya Hidup } & \\
\mathrm{X} 4= & \text { Kualitas Produk } \\
\mathrm{X} 5= & \text { Tempat } \\
\mathrm{X} 6= & \text { Promosi }
\end{aligned}
$$

Adapun interpretasi dari model persamaan regresi di atas adalah sebagai berikut: Nilai Konstanta sebesar 6,239 artinya jika tidak terjadi perubahan variabel harga, kualitas pelayanan, gaya hidup, kualitas produk, tempat, dan promosi maka keputusan pembelian di Pasar Raya 1 bernilai positif dan menunjukkan besarnya pengaruh keputusan pembelian (Y) sebesar 6,239 satuan.

Hasil koefisien regresi X1 sebesar 53,6 persen, maka untuk setiap kenaikan harga sebesar 1 persen akan meningkatkan keputusan pembelian daging sapi di Pasar Raya 1 sebesar 53,6 persen. Begitu juga sebaliknya, apabila harga mengalami penurunan sebesar 1 persen maka keputusan pembelian akan mengalami penurunan sebesar 53,6 persen. Hasil koefisien regresi X2 sebesar $-18,0$ persen, dikarenakan hasil kualitas pelayanan negatif maka dapat disimpulkan bahwa, setiap penurunan kualitas pelayanan sebesar 1 persen maka keputusan pembelian daging sapi di Pasar Raya I sebesar -18,0. Dikarenakan Pasar Raya I merupakan salah satu pasar tradisional, maka dari itu Pasar Raya I tidak memiliki prosedur tertentu mengenai kualitas pelayanan terhadap konsumen. Dari hasil koefisien regresi X3 sebesar -9,4 persen, variabel gaya hidup bernilai negatif maka dapat disimpulkan bahwa, setiap penurunan gaya hidup sebesar 1 persen maka keputusan pembelian daging sapi di Pasar Raya I sebesar -9,4.dikarenakan konsumen daging di Pasar Raya I sebagian besar merupakan para pekerja olahan makanan sehingga variabel gaya hidup mengurangi keputusan pembelian. Dari hasil koefisien regresi X4 sebesar 15,7 persen, maka untuk setiap kenaikan kualitas produk sebesar 1 persen akan meningkatkan keputusan daging sapi di Pasar Raya I sebesar 15,7 persen. Begitu juga sebaliknya, apabila kualitas produk mengalami penurunan sebesar 1 persen maka keputusan pembelian akan mengalami penurunan sebesar 15,7 persen. Dari hasil koefisien regresi X5 sebesar 11,0 persen, maka untuk setiap kenaikan tempat berupa lokasi strategis dan mudah dijangkau sebesar 1 persen akan meningkatkan keputusan pembelian daging sapi di Pasar Raya I sebesar 11,0 persen. Begitu juga sebaliknya, apabila tempat mengalami penurunan 
sebesar 1 persen maka keputusan pembelian akan mengalami penurunan sebesar 11,0. Dari hasil koefisien regresi X6 sebesar 6,8 persen, maka setiap kenaikan promosi sebesar 1 persen akan meningkatkan keputusan pembelian daging sapi di Pasar Raya 1 sebesar 6,8 persen Begitu juga sebaliknya, apabila promosi mengalami penurunan sebesar 1 persen maka keputusan pembelian akan mengalami penurunan sebesar 6,8 persen.

\section{KESIMPULAN}

1. Karakteristik responden yang paling banyak sejumlah 64 orang $(93 \%)$ adalah berjenis kelamin perempuan, 32 orang $(45,7 \%)$ usia $40-49$ tahun, berdasarkan tingkat pendidikan 26 orang ( $37,1 \%)$ SMA

2. Harga (X1), kualitas produk (X4), tempat (X5), berpengaruh signifikan terhadap keputusan pembelian, sedangkan untuk kualitas pelayanan (X2), gaya hidup (X3), promosi (X4), tidak berpengaruh secara signifikan terhadap keputusan pembelian.

\section{DAFTAR PUSTAKA}

Assauri, Sofjan. 2012. Manajemen Pemasaran. Jakarta: PT Raja Grapindo.

Engel, Blackwell, dan M. (1994). Perilaku Konsumen. Jakarta: Binarupa Aksara.

Gitosudarmo, I. 2000. Manajemen Pemasaran, Edisi Pertama. Cetakan Keenam, BPFE. Yogyakarta.

Ghozali, I. (2013). Aplikasi Analisis Multivariate dengan Program SPSS Edis Ketujuh. Semarang: Badan Penerbit Universitas Diponegoro.
Jonathan Sarwono, Metode Penelitian Kuantitatif \& Kualitatif,(Yogyakarta; Graha Ilmu, 2006, Hal. 111)

Hamka, (2014). Pengaruh Harga dan Kualitas Terhadap Keputusan Pembelian Ayam Potong di Pasar Gamalama

Kotler, P. (2008). Manajemen Pemasaran (Edisi $12 \mathrm{~J}$ ). Jakarta: Indeks.

Kotler P dan Keller. 2007. Manajemen Pemasaran: Analisis, Perencanaan, Implementasi dan Pengendalian Edisi Pertama. Jakarta (ID):Prentice Hall

Kasmir. (2004). Bank dan Lembaga Keuangan Lainnya. Jakarta: PT. Raja Grafindo Persada.

Setyarko, Y. (2016). Analisis Persepsi Harga, Promosi, Kualitas Layanan dan Kemudahan Penggunaan Terhadap Keputusan Pembelian Produk Secara Online. Jurnal Ekonomika Dan Manajemen, 5(2), 128-147.

Swasta, B., dan T.H. Handoko., 2000. Manajemen Pemasaran: Analisa dan Perilaku Konsumen. Yogyakarta: BPFE.

Tatag, H, H. (2019). Pengaruh Kualitas Produk dan Kualitas Layanan Terhadap Kepuasan Pelanggan Daging Sapi Beku dan Segar

Yasir, M., Siti, S., \& Ratna N, H. (2010). Pengaruh Kualitas Produk, Saluran Distribusi dan Promosi Terhadap Motif Pembelian Konsumen 